\title{
Peer Review: The Importance Of Education For Best Practice
}

\author{
Lynette R. Goldberg, Wichita State University, USA \\ Douglas F. Parham, Wichita State University, USA \\ Kathy L. Coufal, Wichita State University, USA \\ Masako Maeda, Wichita State University, USA \\ Rosalind R. Scudder, Wichita State University, USA \\ Phillip R. Sechtem, Wichita State University, USA
}

\begin{abstract}
The effectiveness of teaching is expected by an increasingly skeptical public that wants those in higher education to contain costs, increase access, and teach in ways that make sure students learn. An integral and under-used component of documenting teaching effectiveness is peer review. A framework for best practice to ensure a systematic and comprehensive approach to any peer review has been developed and a foundational aspect of this framework is education about the process and its implementation. In the current pilot study, administrators and nonadministrators involved in university teaching were surveyed about their knowledge of, and experiences with, peer review. A striking finding was the notable degree of uncertainty about many components of the process on the part of non-administrators. Results verify the critical importance of education prior to and following any peer review, particularly for instructors in non-administrative positions.
\end{abstract}

Keywords: Peer review, teaching effectiveness, systematic process, reflection, student learning

\section{INTRODUCTION}

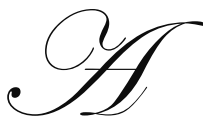

t many academic institutions today, particularly those focused on research, there is ongoing debate about the concepts of, and possible differences between, "the scholarship of teaching and learning," "scholarly teaching," and "teaching as research" (Bernstein, 2008; Healey, 2003; 2008; Shulman

\& Hutchings, 1999; Trigwell, 2008). Instructors engaged in this debate hopefully would agree that they share a commitment to provide teaching that is (a) based on sound theory, (b) infused with current research findings, (c) experiential and contextualized, and (d) strengthened by collaborative input to facilitate and measure student learning. An integral component of this collaborative input is peer review.

Peers are an under-used resource for instructors (Healey, 2008; Keig, 2000; Kynaston, 2007; Macfarlane, 2004). Instructors who are open to constructive critique of their teaching by informed peers are more inclined to show positive accountability to their colleagues, departments and universities. Recognizing that peer review is not a simple task, such constructive critique is best achieved through focused and systematic formative (skill development) and summative (evaluation) reviews of teaching and learning approaches (Blackmore, 2005; Healey, 2008; Kynaston, 2007; McManus, 2001). As instructors work to document the effectiveness of their teaching, they provide a valuable model for students as well as colleagues. This is particularly important to continuously engage students in the scholarship of teaching and learning (Cestone, Levine, \& Lane, 2008).

Peer review may be defined differently among academic institutions, reflecting an array of approaches to the evaluation of teaching (Blackmore, 2005; Cohen \& McKeachie, 1980; McManus, 2001). Broad definitions of peer review include a culture of constructive criticism (Cole, 2003), participatory appraisal (Roberts, 2002), a tool for change (Pagani, 2002), and a method to identify and share positive practices in the evaluation of teaching, including distance and on-line learning (Blackmore, 2005; Keig, 2000; Kynaston, 2007). The differences in peer 
review also may focus on who conducts the review process - senior faculty, expert teachers, educational developers outside the department, within-department faculty observing each other (individually or in small groups; selfselected or appointed), or a combination (Blackmore, 2005; Cosser, 1998; Gosling, 2002).

Some instructors view the diversity of definitions and approaches as a reason for the lack of validity and reliability of the peer review process and thus question its authenticity and usefulness (Chism, 1999; McManus, 2001). Others have mixed reactions to the value of peer reviews for reasons focused on increasing accountability and performance demands by administrators; the need to work well with the people being reviewed (the perceived undermining of teamwork; the lack of accurate feedback as a result of being overly positive); the possibility that less effective teaching strategies will be reinforced by a reviewer who uses the same strategies; and the perception that the review process adversely affects academic freedom (studies cited in Cosser, 1998). The negative reactions to these issues can create apprehension and conflict about the review process (Conley \& Glasman, 2008; Shortland, 2004). Negative reactions to peer reviews also may result from instructors' unfamiliarity with what an effective process should entail (ASHA, 2009). On a positive note, data show that initial resistance can be mitigated by systematic education and personal reflection about the multiple forms of peer review (Blackmore, 2005; Chism, 1999; Courneya, Pratt, \& Collins, 2008). This education includes the available teacher-centered and learningcentered paradigms on which to base decisions about effective teaching (McManus, 2001), and the importance of active and collaborative participation (Hutchings, 1994; Keig, 2000; Smith, Cooper, \& Lancaster, 2002).

Blackmore (2005) developed a best practice framework for peer review which was subsequently verified by Kynaston (2007), and Kell and Annetts (2009). Summarizing previous literature, these investigators advocated the following components for effective peer review: (a) education about the process prior to participation, including the multiple ways in which to evaluate teaching; (b) facilitation of a culture of trust and empowerment; (c) annual implementation; (d) clear documentation of improvements in practice directly linked to a reward system; (e) regular review of the system by all participants, including administrators; (f) systematic changes in who reviews whom, and how, with a focus on checks and balances; and (g) the inclusion of student feedback. Supporting earlier work (e.g., Boyer, 1990; Cosser, 1998; Keig, 2000; McMahon, Barrett, \& O'Neill, 2007; McManus, 2001), Blackmore (2005), Kynaston (2007), and Kell and Annetts (2009) suggested that peer reviews should not be viewed as punitive but used to facilitate reflection on teaching styles, strategies, and philosophies for the benefit of increased student learning.

When peer reviews are implemented, a variety of materials can be reviewed that will complement the observation of teaching. These materials include the instructor's documented teaching philosophy, reflective selfassessments (before, during, and after the review), course portfolios, and course materials. Materials also need to include student evaluations as students are the direct recipients of teaching strategies and thus play an important role in the evaluation of teaching effectiveness (Blackmore, 2005; Kynaston, 2007; McManus, 2001). While complementary, formative (process) and summative (outcome data) evaluations have different purposes. Therefore, each needs to be conducted independently and by different reviewers within and outside of the discipline (Cosser, 1998; Smith \& Tillema, 2007; The National Teaching and Learning Forum, http://www.ntlf.com/html/lib/bib/942dig.htm, retrieved on October 5, 2009). Instructors being reviewed also need sufficient opportunity to prepare for the review and then, following the review, sufficient time to discuss how any suggested improvements in teaching can be implemented. In this way, peer reviews can serve as incentives for instructors to continue to gather data on student learning and empowerment as a measure of the effectiveness of their teaching (Ingram \& Dees, 2009). Such teaching effectiveness is expected by an increasingly skeptical public that wants those in higher education to contain costs, increase access, and teach in ways that make sure students learn (Blackmore, 2005; Clydesdale, 2009; Kirsch, Braun, \& Yamamoto, 2007).

The documented benefits of peer assessment and evaluation for students include increases in (a) accountability and ownership, (b) discussion time and critical analysis, (c) engagement and concentration, (d) confidence, and (e) quality of learning output (studies cited in Cestone et al., 2008). It is logical to consider that these benefits of peer review would apply to instructors provided that evaluations are implemented with skill and respect for the persons being reviewed (Keig, 2000), and that such evaluations are comprehensive and systematic. Instructors at university Teaching and Learning Centers have developed valuable information about the Scholarship of Teaching and Learning and resources for conducting peer reviews and made these resources available on websites 
(e.g., the Peer Evaluation of Teaching [PET] questionnaire and procedures developed at the University of Adelaide, retrieved on September 4, 2009 from http://www.adelaide.edu.au/clpd/evaluation/pet.html; and materials developed at the University of Sydney, http://www.itl.usyd.edu.au/projects/RLT/contact.htm; Illinois State University, http://www.sotl.ilstu.edu/; North Carolina State University, http://www.ncsu.edu/faculty-development/ teachlearn/peer-review.html, Penn State University, http://www.schreyerinstitute.psu.edu/Tools/; the University of Wisconsin-Madison https://tle.wisc.edu/teaching-academy/peer/definiti; and the University of Indiana, http://teaching.iub.edu/ retrieved September 5, 2009).

Despite the increasing focus on the scholarship of teaching and learning, scholarly teaching, and teaching as research, and the fact that external pressure for documentation of effective teaching has existed for many years, there are limited data in refereed journals on the frequency of peer reviews, the manner in which they are conducted and used, their support and effectiveness, and how the process fits with the best practice framework developed by Blackmore (2005). The purpose of this study was to learn more about peer reviews from the experiences of administrative and non-administrative faculty in communication sciences and disorders (CSD) programs across the United States, specifically who completed them and how often, which review methods were employed, the purpose of the review, and how the information was used.

\section{METHOD}

\section{Participants}

One hundred and fifteen instructors (26 males; 89 females) in accredited CSD programs served as participants. These participants were grouped according to their primary responsibilities, i.e., administrative (department chairs or program directors, $\mathrm{n}=44 ; 16$ males:28 females) or non-administrative (instructors/ranked faculty/adjunct faculty, $\mathrm{n}=69$; and clinical educators, $\mathrm{n}=2 ; 10$ males:61 females). All administrators had a doctoral degree. Of the non-administrators who provided data, 50 (70\%; 10 males:45 females) had a doctoral degree (see Table 1). Participants worked in programs that offered either the Masters degree as a terminal degree, or both Masters and doctoral degrees. Time in academia ranged from $<1$ to $>10$ years with $62(54 \%)$ of participants having more than 10 years experience.

The cultural background of participants was White/non-Hispanic $(n=107)$, Black/non-Hispanic $(n=4)$, Asian/Pacific Islander $(n=3)$, and Hispanic $(n=1)$. For 111 participants, English was their primary language. The remaining four participants spoke Spanish as their primary language (see Table 2).

Table: Frequencies and Percentages of All Survey Respondents $(N=115)$

by Administrative Group, Academic Position, Highest Degree Earned, and Gender

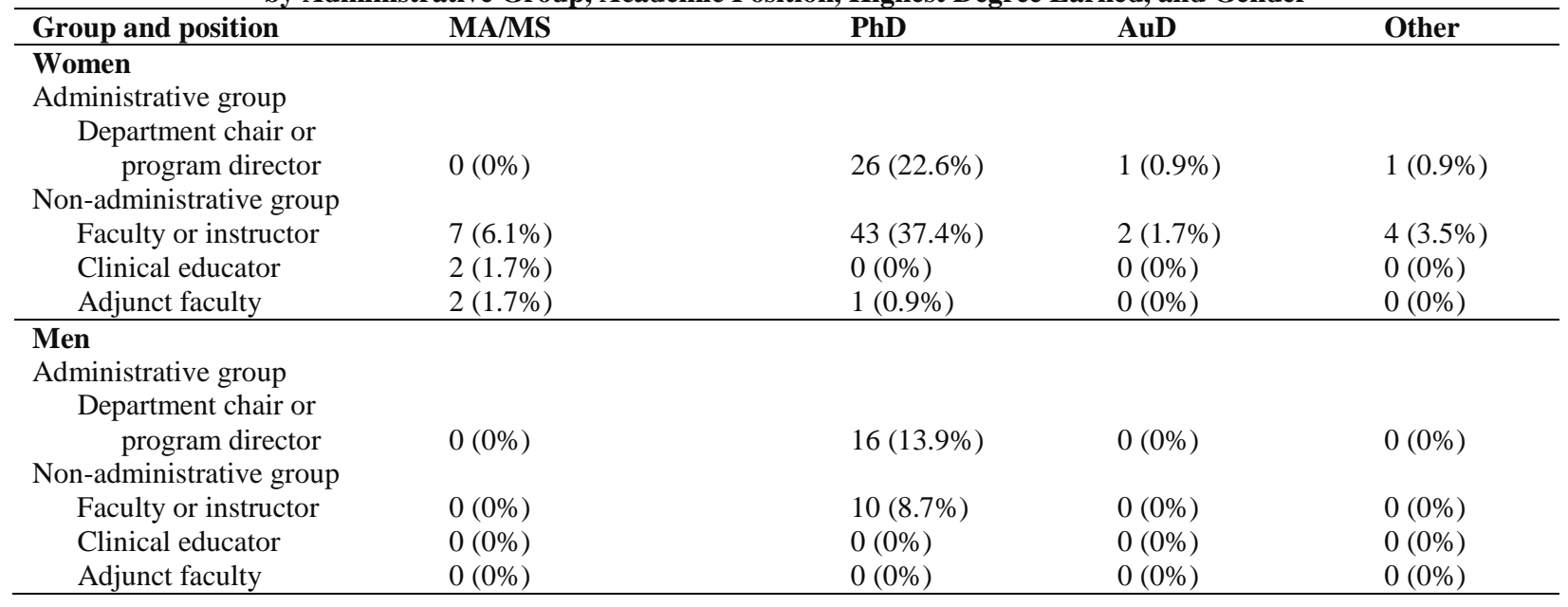




\section{Survey}

A 32-item survey was developed. Demographic questions addressed gender, ethnicity, primary and secondary spoken languages, academic qualifications, teaching experience, primary responsibilities of the participants, and degree programs offered at their University. Subsequent questions related to peer reviews. Specifically, questions asked whether peer reviews were required; their frequency; who served as a peer reviewer; which methods were employed; how data were scored, used and weighted; whether data were supplemented by other sources; the average rating from the reviews; participants' peer review experiences and outcomes, and their opinions of the peer review process. Response formats ranged from forced choice (e.g., questions about gender, primary ethnicity, primary and secondary spoken languages, primary position, level of education, nature of peer reviews, and whether being peer reviewed changed one's teaching) to multiple response options (e.g., who completes the peer review, how the data are obtained and used), with participants asked to mark all relevant options. Examples of questions are provided in Appendix A.

Table 2: Frequencies and Percentages of All Survey Respondents $(N=115)$ by Administrative Group, Academic Position, Race/Ethnicity, and Gender

\begin{tabular}{|c|c|c|c|c|}
\hline Group and position & Asian $^{\mathrm{a}}$ & Black $^{\text {b }}$ & White $^{b}$ & Hispanic \\
\hline \multicolumn{5}{|l|}{ Women } \\
\hline \multicolumn{5}{|l|}{ Administrative group } \\
\hline $\begin{array}{l}\text { Department chair or } \\
\text { program director }\end{array}$ & \multicolumn{4}{|c|}{ Department chair or } \\
\hline \multicolumn{5}{|l|}{ Non-administrative group } \\
\hline Faculty or instructor & $0(0 \%)$ & $4(3.5 \%)$ & $52(45.2 \%)$ & $0(0 \%)$ \\
\hline Clinical educator & $0(0 \%)$ & $0(0 \%)$ & $2(1.7 \%)$ & $0(0 \%)$ \\
\hline Adjunct faculty & $0(0 \%)$ & $0(0 \%)$ & $3(2.6 \%)$ & $0(0 \%)$ \\
\hline \multicolumn{5}{|l|}{ Men } \\
\hline \multicolumn{5}{|l|}{ Administrative group } \\
\hline \multicolumn{5}{|l|}{ Department chair or } \\
\hline \multicolumn{5}{|l|}{ Non-administrative group } \\
\hline Faculty or instructor & $2(1.7 \%)$ & $0(0 \%)$ & $7(6.1 \%)$ & $1(0.9 \%)$ \\
\hline Clinical educator & $0(0 \%)$ & $0(0 \%)$ & $0(0 \%)$ & $0(0 \%)$ \\
\hline Adjunct faculty & $0(0 \%)$ & $0(0 \%)$ & $0(0 \%)$ & $0(0 \%)$ \\
\hline
\end{tabular}

${ }^{a}$ Includes Pacific Islanders and persons of Indian descent. ${ }^{b}$ Non-Hispanic

\section{Procedures}

There are 303 CSD programs in the United States, Puerto Rico, Canada, Australia, and New Zealand that are affiliated with the Council of Graduate Programs in Communication Sciences and Disorders (CAPCSD). Of these, 232 graduate programs in the United States are accredited by the Council on Academic Accreditation (CAA). Once the survey was developed, it was sent on-line to the chairs of these accredited programs with a request that it also be made available to their clinical and academic faculty. The survey remained on-line for completion for three weeks. Each potential participant was informed, via a cover letter, that completion of the survey indicated Informed Consent to participate in the study. Of the 232 CAA-accredited programs, 85 responded. From these 85 programs, 115 participants returned the survey.

\section{Data Analysis}

Participants' responses to each question were coded and entered into Statistical Package for the Social Sciences (SPSS) software (Version 15 for Windows) for analysis. Frequency counts, percentages, and chi-square tests of associations between administrators and non-administrators for the variables under study were calculated (Schiavetti \& Metz, 1997). 


\section{RESULTS}

Demographic data were presented earlier (see Participants). These data are highlighted in Tables 1 and 2.

\section{Questions Related to Peer Review in General}

\section{Institutional Status of Peer Reviews}

All 115 participants responded to the question asking whether peer reviews were required or elective. Among the 44 administrators and 71 non-administrators, there was no significant association between administrative status and whether peer reviews at a given institution were required or elective, $\chi^{2}(2, n=115)=3.41, p=.18$. A majority of administrators $(61.4 \%)$ but less than half of non-administrators $(43.7 \%)$ reported that peer reviews were required. One-fifth of administrators and almost one-third of non-administrators stated that peer reviews were elective (20.5\% and $29.6 \%$, respectively). A total of 27 participants (18.2\% of administrators and $26.8 \%$ of nonadministrators) reported that peer reviews "are not required and therefore not completed." These 27 participants did not complete the remainder of the survey.

The academic position, highest degree earned, gender, and ethnicity of the remaining 36 administrators and 52 non-administrators involved in peer reviews are detailed in Tables 3 and 4.

Table 3: Frequencies and Percentages of Survey Respondents Involved in Peer Reviews $(N=88)$ by Administrative Group, Academic Position, Highest Degree Earned, and Gender

\begin{tabular}{|c|c|c|c|c|}
\hline Group and position & MA/MS & PhD & AuD & Other \\
\hline \multicolumn{5}{|l|}{ Women } \\
\hline \multicolumn{5}{|l|}{ Administrative group } \\
\hline \multicolumn{4}{|l|}{ Department chair or } & $0(0 \%)$ \\
\hline \multicolumn{5}{|l|}{ Non-administrative group } \\
\hline Faculty or instructor & $2(2.3 \%)$ & $35(39.8 \%)$ & $1(1.1 \%)$ & $3(3.4 \%)$ \\
\hline Clinical educator & $2(2.3 \%)$ & $0(0 \%)$ & $0(0 \%)$ & $0(0 \%)$ \\
\hline Adjunct faculty & $2(2.3 \%)$ & $0(0 \%)$ & $0(0 \%)$ & $0(0 \%)$ \\
\hline \multicolumn{5}{|l|}{ Men } \\
\hline \multicolumn{5}{|l|}{ Administrative group } \\
\hline \multicolumn{5}{|l|}{ Department chair or } \\
\hline \multicolumn{5}{|l|}{ Non-administrative group } \\
\hline Faculty or instructor & $0(0 \%)$ & $7(8.0 \%)$ & $0(0 \%)$ & $0(0 \%)$ \\
\hline Clinical educator & $0(0 \%)$ & $0(0 \%)$ & $0(0 \%)$ & $0(0 \%)$ \\
\hline Adjunct faculty & $0(0 \%)$ & $0(0 \%)$ & $0(0 \%)$ & $0(0 \%)$ \\
\hline
\end{tabular}

Peer Reviewers

Among these 88 administrators and non-administrators, there was a significant association between administrative status and the type of agent responsible for conducting peer reviews, $\chi^{2}(4, n=88)=10.12, p=.04$. More non-administrators than administrators stated that peer reviews were conducted internally (within the department) by instructors ( $46.2 \%$ and $22.2 \%$, respectively); more non-administrators admitted that they were unsure who actually had conducted the peer review ( $9.6 \%$ and $2.8 \%$, respectively). Administrators were more likely than non-administrators to report that peer reviews were conducted by administrators $(44.4 \%$ and $32.7 \%$, respectively) or by a combination of internal and external personnel (27.8\% and $11.5 \%$, respectively). Few administrators $(2.8 \%)$ and no non-administrators reported that peer reviews were conducted only by instructors external to the department, e.g., those in a campus Teaching and Learning Center (see Table 5). 
Table 4: Frequencies and Percentages of Survey Respondents Involved in Peer Reviews $(n=88)$ by Administrative Group, Academic Position, Race/Ethnicity, and Gender

\begin{tabular}{|c|c|c|c|c|}
\hline Group and position & Asian $^{a}$ & Black $^{\mathrm{b}}$ & White $^{\text {b }}$ & Hispanic \\
\hline \multicolumn{5}{|l|}{ Women } \\
\hline \multicolumn{5}{|l|}{ Administrative group } \\
\hline $\begin{array}{l}\text { Department chair or } \\
\text { program director }\end{array}$ & $0(0 \%)$ & $0(0 \%)$ & $25(28.4 \%)$ & $0(0 \%)$ \\
\hline \multicolumn{5}{|l|}{ Non-administrative group } \\
\hline Faculty or instructor & $0(0 \%)$ & $2(2.3 \%)$ & $39(44.3 \%)$ & $0(0 \%)$ \\
\hline Clinical educator & $0(0 \%)$ & $0(0 \%)$ & $2(2.3 \%)$ & $0(0 \%)$ \\
\hline Adjunct faculty & $0(0 \%)$ & $0(0 \%)$ & $2(2.3 \%)$ & $0(0 \%)$ \\
\hline \multicolumn{5}{|l|}{ Men } \\
\hline \multicolumn{5}{|l|}{ Administrative group } \\
\hline \multicolumn{5}{|l|}{ Department chair or } \\
\hline \multicolumn{5}{|l|}{ Non-administrative group } \\
\hline Faculty or instructor & $1(1.1 \%)$ & $0(0 \%)$ & $6(6.8 \%)$ & $0(0 \%)$ \\
\hline Clinical educator & $0(0 \%)$ & $0(0 \%)$ & $0(0 \%)$ & $0(0 \%)$ \\
\hline Adjunct faculty & $0(0 \%)$ & $0(0 \%)$ & $0(0 \%)$ & $0(0 \%)$ \\
\hline
\end{tabular}

${ }^{\mathrm{a}}$ Includes Pacific Islanders and persons of Indian descent. ${ }^{\mathrm{b}}$ Non-Hispanic

\section{Frequency of Peer Review}

Among the 36 administrators and 52 non-administrators, there was a significant association between administrative status and the reported frequency with which peer reviews were completed, $\chi^{2}(4, n=88)=16.32, p=$ .003 . A majority of administrators $(58.3 \%)$ and one third of non-administrators $(34.6 \%)$ reported that peer reviews were completed at least once a year; $8.3 \%$ of administrators and $15.4 \%$ of non-administrators stated that peer reviews were completed at least once every two to three years. One third of administrators (33.3\%) and one fifth of non-administrators (19.2\%) reported the frequency to be "other." These three choices accounted for all of the administrative group's selections. Among the non-administrators, nearly one third (28.8\%) admitted being "unsure" of the frequency with which peer reviews were completed (Table 5). Only one non-administrator reported that peer reviews were not completed.

\section{Methods of Peer Review}

There was no significant association between administrative status and the method(s) used to conduct the peer reviews, $\chi^{2}(3, n=88)=5.80, p=.12$. The majority of both administrators $(88.9 \%)$ and non-administrators $(73.1 \%)$ reported that peer reviews consisted of a combination of direct (e.g., observation in the classroom) and indirect (e.g., review of syllabus, teaching portfolio, or videotaped samples of teaching) methods. More nonadministrators than administrators reported that direct observation alone was the method of peer review (11.5\% and $5.6 \%$, respectively). There was a similar distribution between administrators and non-administrators in reporting that only indirect observation was used (5.6\% and 3.8\%, respectively). No administrator was "unsure" about the peer review method(s) used; however $11.5 \%$ of the non-administrators used this response (Table 5).

\section{Peer Review Format}

There was no significant association between administrative status and peer review format, $\chi^{2}(3, n=88)=$ $5.15, p=.16$. The majority of administrators (58.3\%) and a slight majority of non-administrators $(51.9 \%)$ reported using narrative peer reviews. There was a similar distribution between administrators and non-administrators in reporting that the peer review format was a Likert-type scale (2.8\% and $1.9 \%$, respectively). One third of administrators and close to one third of non-administrators used a combination of narrative and Likert-type scale formats (33.3\% and $23.1 \%$, respectively). More non-administrators than administrators were unsure about the type of format used for peer reviews (23.1\% and 5.6\%, respectively) (Table 5). 
Table 5: General Findings Regarding Peer Reviews (in Percentages) and $\chi^{2}$ Comparisons

\begin{tabular}{|c|c|c|c|c|}
\hline Variable & $\begin{array}{c}\text { Admin } \\
(n=36)\end{array}$ & $\begin{array}{c}\text { Non-Admin } \\
(n=52)\end{array}$ & $d f$ & $\chi^{2}$ \\
\hline Type of peer reviewers & & & 4 & $10.12 *$ \\
\hline Instructors in the dept. & 22.2 & 46.2 & & \\
\hline Administrators in the dept. & 44.4 & 32.7 & & \\
\hline Combination of internal and & & & & \\
\hline external personnel & 27.8 & 11.5 & & \\
\hline External instructors only & 2.8 & 0 & & \\
\hline Unsure & 2.8 & 9.6 & & \\
\hline Frequency of peer review & & & 4 & $16.32 * *$ \\
\hline At least once/year & 58.3 & 34.6 & & \\
\hline Once every $2-3$ years & 8.3 & 15.4 & & \\
\hline Other (e.g., as needed) & 33.3 & 19.2 & & \\
\hline Never & 0 & 1.9 & & \\
\hline Unsure & 0 & 28.8 & & \\
\hline Method of peer review & & & 3 & 5.80 \\
\hline Combination of direct and & & & & \\
\hline indirect observation & 88.9 & 73.1 & & \\
\hline Direct observation only & 5.6 & 11.5 & & \\
\hline Indirect observation only & 5.6 & 3.8 & & \\
\hline Unsure & 0 & 11.5 & & \\
\hline Format of peer review & & & 3 & 5.15 \\
\hline Narrative & 58.3 & 51.9 & & \\
\hline Likert-type scale & 2.8 & 1.9 & & \\
\hline Combination of above & 33.3 & 23.1 & & \\
\hline Unsure & 5.6 & 23.1 & & \\
\hline Use of peer review data ${ }^{a}$ & & & 5 & 7.44 \\
\hline $\mathrm{TP}+\mathrm{PU}$ & 52.8 & 53.8 & & \\
\hline $\mathrm{M}+\mathrm{TP}+\mathrm{PU}$ & 22.2 & 11.5 & & \\
\hline $\mathrm{M}+\mathrm{TP}+\mathrm{EY}$ & 0 & 3.8 & & \\
\hline $\mathrm{M}+\mathrm{TP}+\mathrm{EY}+\mathrm{PU}$ & 16.7 & 9.6 & & \\
\hline M only & 8.3 & 11.5 & & \\
\hline Unsure & 0 & 9.6 & & \\
\hline Use of additional data for peer review & & & 2 & $36.14 * * *$ \\
\hline Yes & 86.1 & 21.2 & & \\
\hline No & 0 & 5.8 & & \\
\hline N/A & 13.9 & 73.1 & & \\
\hline
\end{tabular}

Note. $\mathrm{N}=88$

${ }^{\mathrm{a}} \mathrm{TP}=$ tenure and promotion; $\mathrm{PU}=$ personal use $\mathrm{M}=$ merit pay; $\mathrm{EY}=$ end of year reports

$* p<.05 . * * p<.01 . * * * p<.001$

\section{Use of Peer Review Data}

Among the 36 administrators and 52 non-administrators, there was no significant association between administrative status and how peer review data were used, $\chi^{2}(5, n=88)=7.44, p=.19$. The majority of administrators $(52.8 \%)$ and non-administrators (53.8\%) reported that peer reviews were used for both Tenure and Promotion (TP) and personal use (PU). Other response combinations of TP, PU, End-of-Year (EY) and Merit (M) were fewer and are detailed in Table 5. More non-administrators than administrators reported that peer reviews were used solely for merit increases $(11.5 \%$ and $8.3 \%$, respectively). No administrators were unsure of the use of peer review data; however, $9.6 \%$ of non-administrators were unsure.

\section{Use of Additional Data for Peer Review}

Among the 36 administrators and 52 non-administrators, there was a significant association between administrative status and the reported use of additional data to supplement the results of peer reviews when determining such items as merit pay and tenure and promotion, $\chi^{2}(2, n=88)=36.14, p<.001$ (Table 5). Most 
administrators $(86.1 \%)$ and one-fifth of non-administrators $(21.2 \%)$ reported that, when they analyzed peer review data, they used additional data to determine merit pay, tenure and promotion, and to make other performance decisions. A small number of administrators (13.9\%) and almost three-fourths of non-administrators (73.1\%) responded to this question with "N/A."

\section{Questions Related to Individuals Who Had Undergone Peer Review}

Among all of the survey respondents, 27 administrators and 37 non-administrators responded that they had undergone peer reviews. These respondents answered four additional questions.

\section{Personal Meaningfulness of Peer Reviews}

There was no significant association between administrative status and self-reports that peer reviews were personally meaningful, $\chi^{2}(2, n=64)=3.51, p=.17$. The majority of both administrators $(81.5 \%)$ and nonadministrators $(70.3 \%)$ responded that they found the reviews to be personally meaningful (Table 6). More nonadministrators than administrators reported that peer reviews were not meaningful ( $24.3 \%$ and $7.4 \%$, respectively); this trend was reversed when respondents were asked if they were unsure of the meaningfulness of peer reviews ( $11.1 \%$ for administrators, $5.4 \%$ for non-administrators).

\section{In-The-Moment Impact of Peer Reviews on Teaching}

There also was no significant association between administrative status and self-reports that, when being directly observed by a peer reviewer, the instructor changed his/her teaching style, $\chi^{2}(2, n=64)=3.43, p=.18$. The majority of both administrators $(85.2 \%)$ and non-administrators $(64.9 \%)$ reported that they did not change their teaching style while being directly observed for a peer review. When respondents did change their teaching style, non-administrators were more likely $(21.6 \%)$ than administrators $(7.4 \%)$ to do this. More non-administrators $(13.5 \%)$ than administrators $(7.4 \%)$ responded that they were unsure if they made changes to their teaching style when being peer reviewed (Table 6).

\section{Follow-Up Impact of Peer Reviews on Teaching}

There was no significant association between administrative status and self-reports that undergoing peer review resulted in a modification of one's own teaching style, $\chi^{2}(2, n=64)=0.17, p=.92$. The majority of both administrators $(77.8 \%)$ and non-administrators $(81.1 \%)$ reported that they modified their teaching after they had been given the results of the peer review (Table 6). Similar distributions between administrators and nonadministrators were present for respondents answering this question either with "no" (11.1\% and $8.1 \%$, respectively) or with "unsure" (11.1\% and $10.8 \%$, respectively).

\section{Perception of Authenticity of Peer Review}

There was no significant association between administrative status and self-reported perception that peer reviews were authentic and reflected one's own teaching style, $\chi^{2}(2, n=64)=1.13, p=.57$. The majority of the administrators $(70.4 \%)$ and non-administrators $(62.2 \%)$ who had been peer reviewed reported they felt the reviews were conducted authentically and reflected their teaching skills (Table 6). Non-administrators were more likely than administrators to disagree with the authenticity of the peer review process as a reflection of their teaching skills (16.2\% to $7.4 \%)$. There was a similar distribution between administrators and non-administrators for respondents answering this question with "unsure" (22.2\% and $21.6 \%$, respectively). 
Table 6: Findings Regarding Respondents Who Had Undergone Peer Reviews (in Percentages) and $\mathrm{X}^{2}$ Comparisons

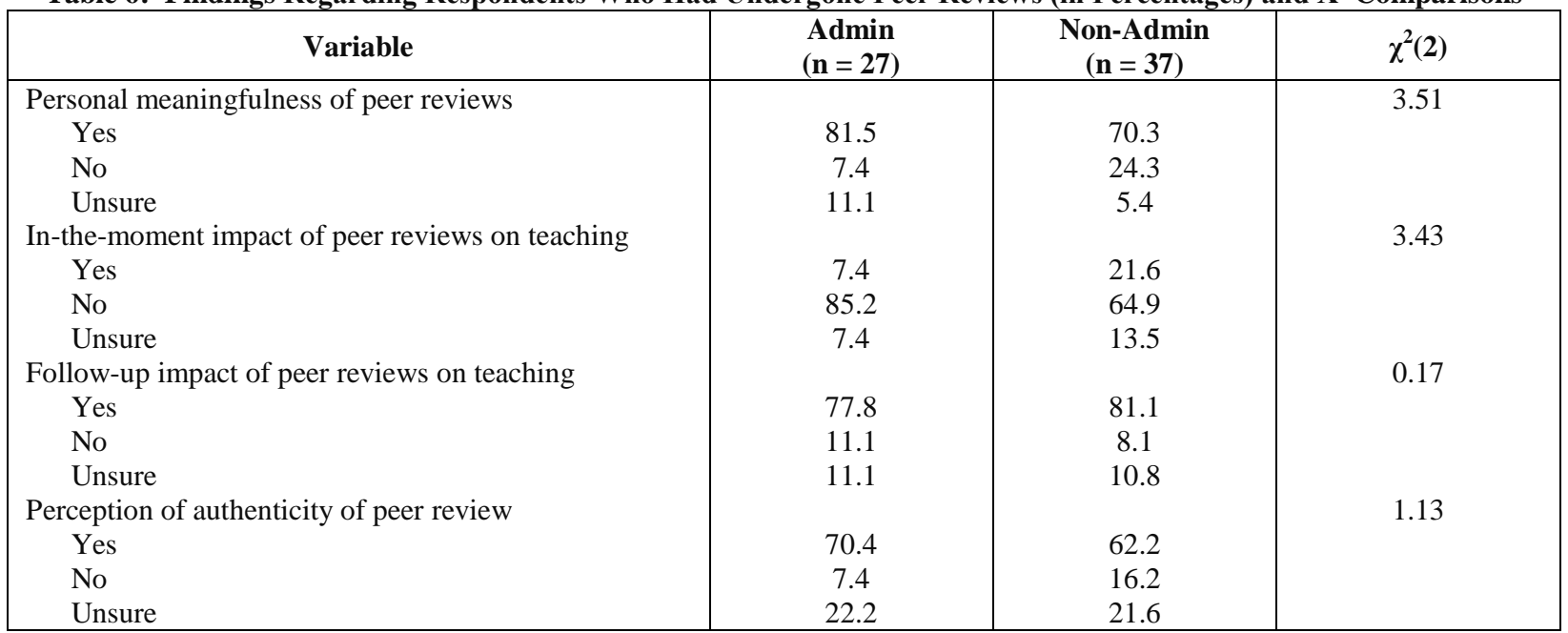

Note. $\mathrm{N}=64$

\section{Questions Related to Individuals Who Had Conducted Peer Reviews}

Respondents who reported conducting peer reviews were asked two additional questions.

\section{Reflection on One's Own Teaching}

Among the 29 administrators and 23 non-administrators who conducted peer reviews, there was no significant association between administrative status and self-reported reflection about, or critique of, one's own teaching as a direct result of being a peer reviewer, $\chi^{2}(2, n=52)=2.27, p=.32$ (Table 7$)$. The majority of administrators $(72.4 \%)$ and a slight majority of non-administrators $(52.2 \%)$ reported that the process of peer reviewing forced them to reflect on their own teaching skills and methods. Non-administrators were more likely than administrators to report that they did not reflect on their own performance as a result of being a peer reviewer ( $17.4 \%$ to $10.3 \%$, respectively). A large percentage of non-administrators responded with "unsure" (30.4\%, compared with $17.2 \%$ of administrators).

\section{Modification of One's Own Teaching}

Among these 29 administrators and 23 non-administrators there also was no significant association between administrative status and self-reported actual modification of teaching as a direct result of being a peer reviewer, $\chi^{2}$ $(2, \mathrm{n}=52)=1.93, p=.38$ (Table 7$)$. The majority of both administrators $(75.9 \%)$ and non-administrators $(87.0 \%)$ reported that they had modified their teaching styles as a result of being a peer reviewer. There was a similar distribution between administrators and non-administrators when responding that being a peer reviewer had not caused them to change their own teaching methods (17.2\% and $13.0 \%$, respectively). A response of "unsure" was selected by a small percent of administrators (6.9\%) and none of the non-administrators.

\section{Follow-up Analyses on the Potential Effects of Gender and Length of Experience}

The focus of the current inquiry was on potential differences between administrators and nonadministrators regarding the peer-review process. To explore the possible effects of gender and length of experience on how participants responded as administrators and non-administrators, chi-square tests of associations were calculated for the questions answered by those who had undergone peer review and those who had conducted peer reviews. Length-of-experience was grouped as less than one year; one to three years; four to six years; seven to 10 years; and greater than 10 years. There was no significant association between gender or length of experience for any of the factors under study regarding peer review, specifically its personal meaningfulness; immediate (in-the- 
moment) impact; follow-up impact; perceived authenticity; and impact on the reflection and modification of one's own teaching.

Table 7: Findings Regarding Respondents Who had Conducted Peer Reviews (in Percentages) and $\chi^{2}$ Comparisons

\begin{tabular}{|l|c|c|c|}
\hline \multicolumn{1}{|c|}{ Variable } & $\begin{array}{c}\text { Admin } \\
(\boldsymbol{n}=\mathbf{2 9})\end{array}$ & $\begin{array}{c}\text { Non-Admin } \\
(\boldsymbol{n}=\mathbf{2 3})\end{array}$ & $\chi^{\mathbf{2}(\mathbf{2})}$ \\
\hline Reflection on one's own teaching & & & 2.27 \\
$\quad$ Yes & 72.4 & 52.2 & \\
No & 10.3 & 17.4 & 1.93 \\
Unsure & 17.2 & 30.4 & \\
Modification of one's own teaching & 75.9 & 87.0 & \\
$\quad$ Yes & 17.2 & 13.0 & \\
No & 6.9 & 0 & \\
Unsure & & \\
\hline
\end{tabular}

Note. $\mathrm{N}=52$

\section{DISCUSSION}

Instructors and administrators in Higher Education today face increasing demands for accountability, particularly in demonstrating that they are able to actively engage students in contextualized and deep, rather than surface, learning. The valuable concept of academic freedom allows instructors to employ a variety of meaningful and theoretically-based teaching and learning strategies. However, instructors must be able to show that the strategies upon which they rely do indeed resonate with students and result in positive learning outcomes. An important and under-used resource in documenting the effectiveness of teaching is constructive and systematic input from knowledgeable and insightful peers (Blackmore, 2005; Courneya et al., 2009; Healey, 2008; Kynaston, 2007; McMahon et al., 2007; Smith \& Tillema, 2007).

In addition to being recognized for their own teaching ability, knowledgeable and insightful peers need to consider all components of an effective peer review process. These components include making sure the instructor being reviewed (a) understands and feels a part of the process, (b) has sufficient time to prepare a variety of materials for the peer reviewer(s), including the goals and objectives for the observed class, and (c) has the opportunity to meet with the reviewer(s) following the class observation to discuss and reflect upon any suggested changes in teaching approach. Two additional components are completing reviews regularly, comprehensively, and systematically, and making sure that the persons conducting the reviews are able to view teaching in a larger context, as opposed to judging specific behaviors. Peer reviewers thus can serve as mentors and set the stage for positive review experiences that are motivating and reinforcing.

Results of the current pilot study, although constrained by a limited number of participants, showed that the majority of administrators and non-administrators used both direct and indirect methods in peer reviews and documented their observations through narrative and Likert-type scales. More administrators than nonadministrators reported that peer reviews were required and completed at least annually, with data used systematically and complemented by data from additional sources to assist with performance-related decisions. More administrators also reported that serving as a peer reviewer facilitated reflection about their own teaching performance. These findings suggest that the administrators and non-administrators in this study had differing interpretations of many aspects of the peer review process. In particular, administrators viewed the process more formally and with more certainty than non-administrators. While this makes sense given the work responsibilities of administrators, it is equally important for non-administrators to appreciate the comprehensive nature of effective peer reviews.

In the current study, the percentage of non-administrators who were unsure of important components in the peer review process was striking. In contrast to the majority of administrators, many non-administrators did not know who conducted the peer reviews, how often they were conducted, which methods were used, the reasons for the peer reviews, and the value of complementary data from additional sources. Many non-administrators also were 
unsure if being peer reviewed or reviewing others helped them to reflect on their own teaching and make any enhancements.

It is interesting to consider the possible reasons for this disturbing finding of uncertainty. One suggestion could be that the non-administrators were complacent about the peer review process. However, if this were the case, it is surprising that these participants voluntarily made the time to respond to the survey. A more plausible reason could be that there was little or no follow-up to completed peer reviews and consequently many non-administrators felt they were unable to provide accurate responses to many of the posed questions. A further reason could reflect the non-administrators' lack of knowledge about the importance of a comprehensive and systematic approach to peer reviews, particularly the inclusion of both formative and summative evaluations, and the insight gained from pre- and post-reflections. All three possible reasons could be interwoven but accurate education about the peer review process would appear to be the important foundation.

Remaining unaware of the full range of components of an effective peer review process heightens the risk for those being peer reviewed, or serving as reviewers, to (a) feel anxious about the review process, (b) perceive negatively that it is being imposed upon them, and (c) consider the process meaningless or in-authentic, particularly as it relates to performance incentives and inter-personal respect (Cosser, 1998; Kynaston, 2007). Instructors can convey this negative attitude to students and colleagues, and miss the opportunity for positive, collaborative input to enhance their teaching and their role within the university. Given the best practice framework developed by Blackmore (2005), the value of team, triad, or paired reviewers (Gosling, 2002; Smith \& Tillema, 2007), and the array of available on-line resources, it is important for both administrators and non-administrators to work together to implement a clearly-focused and systematic peer review program. In this working partnership, administrators and non-administrators can, on a regular basis, set aside sufficient time to discuss emerging data that document how peer reviews can improve teaching and learning, enhance awareness of student needs, and facilitate department faculty acting as a team (Kell \& Annetts, 2009; Kynaston, 2007). Effective peer reviews also can promote team-teaching (Cosser, 1998; Kynaston, 2007), an increasingly important consideration within and across academic departments. The importance of learning from any peer review, discussing specific strategies in response to observations, and repeating the review at a future date will facilitate the $360^{\circ}$ assessment of teaching faculty that is an integral aspect of the documentation of student learning.

\section{AUTHOR INFORMATION}

Dr. Lyn Goldberg is an Associate Professor in the department of Communication Sciences and Disorders (CSD) at Wichita State University. She is a member of the International Society for the Scholarship of Teaching and Learning (ISSoTL). Her research includes quantitative and qualitative measurement of the effectiveness of inter-professional teaching and student learning.

Dr. Douglas F. Parham is an Assistant Professor in CSD at Wichita State University. He received his PhD from The University of Memphis. His primary research interests are speech development, acoustic phonetics, communicative interaction, and statistical measurement.

Dr. Kathy L. Coufal is Professor and Chair of the CSD Department at Wichita State University. In that role, she has been investigating the peer review process and how to best institute meaningful peer reviews into faculty annual review.

Masako Maeda is a PhD candidate in the CSD Department at Wichita State University. She has a master's degree in Curriculum and Instruction. Her doctoral study focuses on the pedagogy of foreign accent modification for Japanese adults and teaching English as a second/foreign language.

Dr. Rosalind Scudder is a Professor in the CSD Department and the Director of the Leadership Program in Teaching and Learning in the College of Health Professions at Wichita State University.

Phillip R. Sechtem is a PhD candidate in the CSD Department at Wichita State University. He also holds a faculty position in communication sciences and disorders at Fort Hayes State University in Hays, Kansas. His research interests include teaching, supervision, and issues in swallowing dysfunction. 


\section{REFERENCES}

1. American Speech-Language-Hearing Association (2009). Scholarship of teaching and learning survey results. Unpublished paper. Rockville, MD: Author.

2. Bernstein, D. J. (2008). Peer review and evaluation of the intellectual work of teaching. Change, 20(2), 4851 .

3. Blackmore, J.A. (2005). A critical evaluation of peer review via teaching observation within higher education. International Journal of Educational Management, 19(3), 218-232.

4. Boyer, E. (1990). Scholarship reconsidered: Priorities of the professoriate. Princeton, NJ: The Carnegie Foundation for the Advancement of Teaching.

5. $\quad$ Cestone, C.M., Levine, R.E., \& Lane, D.R. (2008). Peer assessment and evaluation in team-based learning. New Directions for Teaching and Learning, 116 (Winter), 69-78.

6. Chism, N. (1999). Peer review of teaching: A sourcebook. Boston, MA: Anker Publishing Co.

7. Clydesdale, T. (2009, January 23). Wake up and smell the new epistemology. The Chronicle of Higher Education, 55(20), B7.

8. Cohen, P.A., \& McKeachie, W.J. (1980). The role of colleagues in the evaluation of college teaching. Improving College and University Teaching, 28, 147-154.

9. Cole, R.E. (2003). New organizational designs for sustainable quality improvement. Key note address, Proceedings from the $6^{\text {th }}$ International Conference on Quality Management and Organisational Development (QMOD), Paris.

10. Conley, S., \& Glasman, N. (2008). Fear, the school organization, and teacher evaluation. Education Policy, 22(1), 63-85.

11. Cosser, M. (1998). Towards the design of a system of peer review of teaching for the advancement of the individual within the university. Higher Education, 35, 143-162.

12. Courneya, C-A., Pratt, D.D., \& Collins, J. (2008). Through what perspective do we judge the teaching of peers? Teaching and Teacher Education, 24, 69-79.

13. Gosling, D. (2002). Models of peer observation of teaching, August, LTSN Generic Centre Learning and Teaching Support Network, York.

14. Healey, M. (2003). The scholarship of teaching: Issues around an evolving concept. Journal on Excellence in College Teaching, 14(1/2), 5-26.

15. Healey, M. (2008). Assessing the connections between academics" experiences of "research" and "teaching": Investigating disciplinary and institutional variations. Presentation at the annual conference of the International Society for the Scholarship of Teaching and Learning, Edmonton, Canada.

16. Hutchings, P. (1994). Peer review of teaching: From idea to prototype. AAHE Bulletin, 47(3), 3-7.

17. Ingram, A., \& Dees, D.M. (2009). "A little help from our friends...”: Improving teaching with peer reviews. Unpublished paper, Rochester Institute of Technology.

18. Keig, L. (2000). Formative peer review of teaching: Attitudes of faculty at liberal arts colleges toward colleague assessment. Journal of Personnel Evaluation in Education, 14(1), 67-87.

19. Kell, C., \& Annetts, S. (2009). Peer review of teaching: Embedded practice or policy-holding complacency? Innovations in Education and Teaching International, 46(1), 61-70.

20. Kirsch, I., Braun, H., \& Yamamoto, K. (2007). America's perfect storm: Three forces changing our nation's future. Princeton, NJ: Educational Testing Service.

21. Kynaston, R. (August 2007). Peer review framework evaluation. Unpublished manuscript. Liverpool JMU, UK.

22. Macfarlane, B. (2004). Teaching with integrity: The ethics of higher education practice. Routledge-Falmer, London.

23. McMahon, T., Barrett, T., \& O’Neill, G. (2007). Using observation of teaching to improve quality: Finding your way through the muddle of competing conceptions, confusion of practice, and mutually exclusive intentions. Teaching in Higher Education, 12(4), 499-511.

24. McManus, D.A. (2001). The two paradigms of education and the peer review of teaching. Journal of Geoscience Education, 49(5), 423-434.

25. Pagani, F. (2002). Peer review: A tool for global co-operation and change. Observer, No. 235, December.

26. Roberts, G.E. (2002). Employee performance appraisal system participation: A technique that works. Public Personnel Management, 31(3), 333-342. 
27. Schiavetti, N., \& Metz, D.E. (1997). Evaluating research in communicative disorders. Boston, MA: Allyn and Bacon.

28. Shortland, S. (2004). Peer observation: A tool for staff development or compliance. Journal of Further and Higher Education, 28(2), 219-228.

29. Shulman, L., \& Hutchings, P. (1999 September/October). The scholarship of teaching: New elaborations, new developments. Change, $31,5$.

30. Smith, H., Cooper, A., \& Lancaster, L. (2002). Improving the quality of undergraduate peer assessment: A case for student and staff development. Innovations in Education and Teaching International, 39(1), 71-81.

31. Smith, K., \& Tillema, H.H. (2007). Use of criteria in assessing teaching portfolio: Judgmental practices in summative evaluation. Scandinavian Journal of Educational Research, 51(1), 103-117.

32. Trigwell, K. (2008, October). The struggle for connections. Plenary presentation at the annual conference of the International Society for the Scholarship of Teaching and Learning, Edmonton, Canada. 


\section{APPENDIX A}

\section{Examples of Survey Questions Regarding Peer Reviews}

1. Peer reviews of teachers in your department are completed (check all that apply):

- Internally (by teachers within your department)

- Externally (by other teachers from outside your department)

- By administrators (chairs, directors, deans)

- By a teaching center professional

- By a peer of your choice

- Unsure

2. Peer reviews of teachers where you work are completed:

- At least once per year

- At least once every 2-3 years

- They are not completed

- Unsure

3. The method(s) used to conduct peer teacher reviews consist of (check all that apply):

- Direct observations (observed in the classroom)

- Indirect observations (e.g., video samples of actual teaching)

- Pre- and post-observations discussions and feedback

- Syllabus reviews

- Teaching portfolios

- Unsure

4. The format of the peer reviews consists of (check all that apply):

- Narrative

- Likert-type scales

- A combination of these

- Unsure

5. How are data of peer reviews used where you work (check all that apply)?

- For merit pay determination

- For tenure and promotion purposes

- For data required for year-end reports

- For your own use

- Unsure

6. Does conducting peer reviews force you to take a hard look at your skills, methods, abilities, and performance?

- Yes

- No

- Unsure 